\title{
Interactive Mixed Reality Technology for Boosting the Level of Museum Engagement
}

\author{
Ramy Hammady ${ }^{\mathrm{ab}}$, and \\ Minhua $\mathrm{Ma}^{*}$ \\ a School of Media Arts and Technology \\ Solent University, United Kingdom \\ ramy.hammady@solent.ac.uk \\ ${ }^{\mathrm{b}}$ Helwan University \\ Giza, Egypt \\ * Falmouth University, United Kingdom \\ m.ma@falmouth.ac.uk
}

\begin{abstract}
Holographic immersive technology such as 'Mixed Reality' is nowadays extending in the cultural heritage sector to open new prospects to engage visitors in museums. This paper investigates the level of engagement in the museum space by conducting observations and time consuming at the Egyptian Museum in Cairo. An interactive mixed reality system named 'MuseumEye' was developed and used Microsoft HoloLens as a mixed reality head mounted display to boost the level of engagement with the exhibited antiques. This system was experienced by 171 of the Egyptian museum visitors and another observation was conducted to record their behaviours and the time they consumed next to each antique. Results of this study showed the time consumed to engage with holographic visuals and the exhibited has been increased 4 times compared to the time the visitors consumed before without using technological gadgets. The implications of these immersive technologies can be an important vehicle for driving the tourism industries towards achieving successful engaging experiences.
\end{abstract}

Keywords: Microsoft HoloLens; Engagement; Museums; Usability; Mixed Reality; Observation.

\section{Introduction}

Mixed Reality (MR) is trending the last few years on enhancing the museum engagement and the visiting experience when it incorporates with museum tours (Hou, 2019; Pollalis et al., 2018). Engagement is defined in different manners by different authors (Brodie, Ilic, Juric, \& Hollebeek, 2013; Higgins \& Scholer, 2009), such as attachment (Dwayne Ball \& Tasaki, 1992), or emotional connection (Marci, 2006). Taheri, Jafari, and O'Gorman (2014) identified three drivers for engagement in tourism: prior knowledge, multiple motivations and cultural capital. Regarding engagement in museums, it enhances the visitors' consumption experience (Edmonds, Muller, \& Connell, 2006). Normally, successful engagement is measured in museums by the average time spent in the space. However, the time may be consumed in other facilities in the museum such as the coffee shop (J. Falk \& Storksdieck, 2005). Therefore, engagement for museum visitors is better represented in spending time with the interpretation techniques and creative presentations (Welsh, 2005). 
HoloMuse as MR system impacted on boosting the level of engagement by incorporating interactive holographic in museums that can be manipulated by hand gestures (Pollalis, Fahnbulleh, Tynes, \& Shaer, 2017). Other scholars used MR storytelling on the exhibits to engage visitors (Darzentas, Flintham, \& Benford, 2018). Also, MR technology has been exploited to produce multiplayer games in museums to increase the engagement with co-visitors in museum spaces (Holloway-Attaway \& Rouse, 2018). Many scholars attempted to engage visitors with the cutting-edge of MR systems and headset, however very few emphasised on providing an evidence of an actual impact these technologies on the museum engagement. This study employed a series of observation studies to provide metrics that can measure the level of engagement in museums specifically after adopting MR technologies. Also, this study built a new interactive holographic MR system using Microsoft HoloLens as a headset to boost the level of engagement at the Egyptian Museum in Cairo.

\subsection{Pre-study}

Based on a prior interview with one of the Cairo museum's curators, it was stated that either national or international museum visitors usually spend an average one hour in the museum, including roaming and touring. Based on the nature of the museum and its number of collections and rooms, this phenomenon was unusual as it also contradicts other studies that report that the average time spent in museums varies between 120 and 180 minutes (Chia, Yeong, Lee, \& Ch'ng, 2016), and between 90 and 240 minutes in the Louvre museum (Yoshimura, Krebs, \& Ratti, 2016). Many factors, can influence the time spent in museums such as economic, psychological, socio-demographic, triprelated factors (Brida, Nogare, \& Scuderi, 2017), entry time, exhibits and number of visitors (Yoshimura et al., 2016). This research focuses on the time spent in front of the exhibited antiques and investigates how the visual experience and information was retained during the tour. A methodological exploration action was planned to take place due to the lack of essential information that the research could acquire from the literature review.

The prior observational studies used the approach of the random time sampling technique to capture the time consumed in the room of King Tutankhamun, which is located on the second level of the Egyptian museum. The observational study captured 20 participants of the daily museum visitors via a fixed camera fitted to different locations at different times. Visitors who observed where stood next to 4 different exhibits that belongs to the King Tut. The preliminary exploratory observation concluded that forty seconds was the average duration that visitors usually spend in the museum room without using guide tools or gadgets.

The average of the time spent is $=$ (total spent time by sampled visitors) $812 \div$ (number of sampled visitors) $20=40 \mathrm{sec}$.

This research adds to the snowballing body of evidence that MR technology can reshape and change the museum visitor's experience.

\section{System overview}

In order to measure the influence of the MR technology on the touristic engagement levels, this research embarked to create an interactive holographic MR system using 
Microsoft HoloLens (Microsoft, 2015) as a holographic immersive headset that supports the mobility and hand gestures interactions for users on the spot of action. The system made to cover 10 antiques in the museum room.

\subsection{Functionality}

For the sake of fulfilling all visitors' needs and accomplishing the museum guide's objectives, a comprehensive list of functions - depicted in Table 1-was formed. Some functions were adopted from previous mobile guide studies that were suitable for the nature of the system. Also, several other new functions were built to exploit the device's abilities and achieve the aim of the system.

Museum professionals were involved in discussing the proposed functions in order to evaluate them with respect to different museum exhibits. Also, software developers were invited to discuss the possibility of the proposed functions from a technical perspective.

The system functions vary according to their classification, which can define the particular action that the visitor performs while using the system. The categories were tackled as per the below descriptions. Fig. 1 demonstrates the functionality of MuseumEye next to the museum exhibits.

1- Visual Communication: It is necessary to achieve direct communication between the visitor's senses and the system's visual and audio sources, as part of the immersive experience. So, a set of functions were designed to enrich the experience with various forms of communication during the tour such as spatial scenery, and animated avatars.

2- Guidance: This involves a set of functions that involve visual and acoustical signs and cues, which guide the visitor around the museum room e.g. holographic labels, images, videos and interactive virtual replica of the authentic antique.

3- Interaction: This involves set of functions that utilise the headset's hand gestures to interact with spatial visuals. These functions aim to open up several ways of interaction between the visitor and the two realms; e.g. User interface (navigation and controls), interactive portals for each antique and knowledge scale game.

4- Communication: This is essential to create lines of communication between the visitor and the virtual guide to transfer knowledge and give instructions, using audio and visual clues. These functions are such as; virtual storyteller of the King himself, audio narration, capture images and collaborative shared experience.

\begin{tabular}{|l|l|l|l|}
\hline $\begin{array}{c}\text { Functions/ } \\
\text { Tasks }\end{array}$ & \multicolumn{1}{c|}{ Description } & \multicolumn{1}{c|}{ Category } & \multicolumn{1}{c|}{ Purpose } \\
\hline Spatial scenery & $\begin{array}{l}\text { It represents historical scenes } \\
\text { composed of buildings, } \\
\text { antiques and representations of } \\
\text { characters - ancient Egyptian } \\
\text { gods - considered to have } \\
\text { spiritual power in ancient } \\
\text { Egyptian culture. All of these } \\
\text { virtual items will be mapped }\end{array}$ & $\begin{array}{l}\text { Visual } \\
\text { communication }\end{array}$ & $\begin{array}{l}\text { Make the visitor fully } \\
\text { immersed in both realms. }\end{array}$ \\
\hline
\end{tabular}




\begin{tabular}{|c|c|c|c|}
\hline $\begin{array}{c}\text { Functions/ } \\
\text { Tasks }\end{array}$ & Description & Category & Purpose \\
\hline & $\begin{array}{l}\text { and superimposed on top of the } \\
\text { physical room including } \\
\text { ceiling, walls and floor. }\end{array}$ & & \\
\hline $\begin{array}{l}\text { Storytelling by } \\
\text { virtual guide } \\
\text { performance }\end{array}$ & $\begin{array}{l}\text { Stories or narrative content } \\
\text { were synthesised from reliable } \\
\text { sources. This content is } \\
\text { animated and performed by the } \\
\text { virtual guide who is the avatar } \\
\text { of King Tutankhamun. The } \\
\text { explanation is supplemented } \\
\text { and synchronised by images } \\
\text { which are augmented where the } \\
\text { guide points. } \\
\text { The virtual Tutankhamun is } \\
\text { life-size, and his way of acting } \\
\text { is like as a human guide. }\end{array}$ & Communication & $\begin{array}{l}\text { Enrich the visitor with } \\
\text { contextual information in an } \\
\text { interesting manner. } \\
\text { Providing the visitor with a } \\
\text { customised guide so the visitor } \\
\text { can listen and watch the } \\
\text { explanation. }\end{array}$ \\
\hline Script Text & $\begin{array}{l}\text { A visible script in text format, to } \\
\text { be triggered by the user. }\end{array}$ & Guidance & $\begin{array}{l}\text { It allows visitors to catch up } \\
\text { with the ongoing explanation } \\
\text { if part of it was missed. It } \\
\text { provides an additional channel } \\
\text { specifically for visitors with } \\
\text { hearing loss. }\end{array}$ \\
\hline Images & $\begin{array}{l}\text { Augmented images upon visitor } \\
\text { hand interaction. These images } \\
\text { represented the antique's } \\
\text { condition when it was } \\
\text { discovered. Moreover, these } \\
\text { images were taken by the } \\
\text { discoverer of the exhibited } \\
\text { item. }\end{array}$ & Guidance & $\begin{array}{l}\text { Enrich the content with } \\
\text { different layers of visual } \\
\text { information. Moreover, most } \\
\text { of these images are not } \\
\text { available to visitors. Bringing } \\
\text { these images while seeing the } \\
\text { real antique is beneficial. It } \\
\text { also exposes visitors to in- } \\
\text { depth visual information if } \\
\text { they are interested in more } \\
\text { exploration. }\end{array}$ \\
\hline
\end{tabular}




\begin{tabular}{|c|c|c|c|}
\hline $\begin{array}{c}\text { Functions/ } \\
\text { Tasks }\end{array}$ & Description & Category & Purpose \\
\hline $\begin{array}{l}\text { Audio } \\
\text { narration }\end{array}$ & $\begin{array}{l}\text { Audio commentaries by a } \\
\text { narrator were produced from } \\
\text { academic references in an } \\
\text { interesting manner. They are } \\
\text { synchronised with displayed } \\
\text { images that are referred to in } \\
\text { the commentaries for further } \\
\text { clarification. }\end{array}$ & Communication & $\begin{array}{l}\text { This function is the essence of } \\
\text { museum guidance, is to listen } \\
\text { to a guide and look at the } \\
\text { antique simultaneously. It } \\
\text { provides an effective response } \\
\text { to one of the patterns observed } \\
\text { among visitors, namely the } \\
\text { tendency to read labels with } \\
\text { loud voices. Therefore, this } \\
\text { function is built to ease the } \\
\text { mission of reading to others } \\
\text { aesthetically. }\end{array}$ \\
\hline $\begin{array}{l}\text { Air tap/ Hand } \\
\text { interactions }\end{array}$ & $\begin{array}{l}\text { Interaction - by hand gestures } \\
\text { such as air tapping- is possible } \\
\text { in several ways: } \\
\text { - Moving between scene } \\
\text { - Reveal item's images } \\
\text { - Reveal item's script text } \\
\text { - Use the UI navigation buttons } \\
\text { - Spin or rotate the virtual } \\
\text { replica of the item. }\end{array}$ & Interaction & $\begin{array}{l}\text { Interactions can boost the level } \\
\text { of engagement with visitors. } \\
\text { As long as the user keeps } \\
\text { interacting with the system, it } \\
\text { means the information } \\
\text { continues to feed into the user. } \\
\text { Therefore, demanding } \\
\text { information is a positive sign } \\
\text { for knowledge retention. }\end{array}$ \\
\hline $\begin{array}{l}\text { Knowledge } \\
\text { scale game }\end{array}$ & $\begin{array}{l}\text { It is an interactive game for } \\
\text { discovering secret and thrilling } \\
\text { information about each antique. } \\
\text { Around each antique, there are } \\
\text { small interactive circles, which } \\
\text { reveal secret information next } \\
\text { to them. It reveals this } \\
\text { information by spinning the } \\
\text { antique via hand gestures of the } \\
\text { user's hands. }\end{array}$ & Interaction & $\begin{array}{l}\text { This educational interactive is } \\
\text { designed to improve user } \\
\text { engagement and information } \\
\text { retention. }\end{array}$ \\
\hline Videos & $\begin{array}{l}\text { An introductory and } \\
\text { informative video about the } \\
\text { museum collections and the } \\
\text { particular collection exhibited } \\
\text { is covered in the system. }\end{array}$ & Guidance & $\begin{array}{l}\text { Watching videos during the } \\
\text { experience will add diversity } \\
\text { to multimedia visuals. Videos } \\
\text { have visual effects, text and } \\
\text { images, created to be } \\
\text { interesting for the visitor. } \\
\text { Also, the visitor can skip the } \\
\text { displayed video if he/she gets } \\
\text { bored. }\end{array}$ \\
\hline
\end{tabular}




\begin{tabular}{|c|c|c|c|}
\hline $\begin{array}{c}\text { Functions/ } \\
\text { Tasks }\end{array}$ & Description & Category & Purpose \\
\hline $\begin{array}{l}\text { Scenes portal } \\
\text { points }\end{array}$ & $\begin{array}{l}\text { Based on HoloLens' user } \\
\text { location hotspots feature, } \\
\text { MuseumEye provides } \\
\text { interactive scene portals that } \\
\text { are placed at key areas of } \\
\text { interest. Once the user stands } \\
\text { on top of it, it takes the visitor } \\
\text { to the particular scene which is } \\
\text { relevant to the item at that } \\
\text { position. }\end{array}$ & Guidance & $\begin{array}{l}\text { It is a direct and physical way } \\
\text { to access scenes that include } \\
\text { the particular guided methods, } \\
\text { relevant to each exhibited } \\
\text { antique. It is also part of the } \\
\text { multi- scenarios design of the } \\
\text { tour. }\end{array}$ \\
\hline $\begin{array}{l}\text { Orientation of } \\
\text { Portal points }\end{array}$ & $\begin{array}{l}\text { Auto-orientation occurs of the } \\
\text { portal points that are capable of } \\
\text { facing the visitor's position. } \\
\text { Portal names will always face } \\
\text { the visitor. }\end{array}$ & $\begin{array}{l}\text { Visual } \\
\text { Communication }\end{array}$ & $\begin{array}{l}\text { Auto-orientation of the text is } \\
\text { a fundamental ergonomic } \\
\text { aspect of the system. The title } \\
\text { of the scene informs the user } \\
\text { of the name of the exhibited } \\
\text { item if the user is at a distance } \\
\text { from the item. Besides, it } \\
\text { provides access to the scene. }\end{array}$ \\
\hline $\begin{array}{l}\text { Taking a photo } \\
\text { / screenshot }\end{array}$ & $\begin{array}{l}\text { The visitor can take a picture or } \\
\text { screenshot of what he sees in } \\
\text { MuseumEye using a voice } \\
\text { command. }\end{array}$ & Communication & $\begin{array}{l}\text { This function allows the user to } \\
\text { capture and share what he/she } \\
\text { sees to others. } \\
\text { It is a response to the museum } \\
\text { visitors' behaviour pattern, } \\
\text { which was discovered in the } \\
\text { pre-study observational } \\
\text { analysis, namely the tendency } \\
\text { to take photos. }\end{array}$ \\
\hline $\begin{array}{l}\text { Collaborative } \\
\text { shared } \\
\text { experience }\end{array}$ & $\begin{array}{l}\text { It allows a group of visitors } \\
\text { who wear the HoloLens } \\
\text { headsets to see what the single } \\
\text { visitor can see. It is a } \\
\text { collaborative experience, which } \\
\text { means all interactions are also } \\
\text { possible for co-visitors who are } \\
\text { in the same network } \\
\text { connection. }\end{array}$ & Communication & $\begin{array}{l}\text { This function encourages } \\
\text { social interaction and opens } \\
\text { prospects for open discussion } \\
\text { between visitors. Hence, more } \\
\text { interaction leads to gaining } \\
\text { more knowledge about the } \\
\text { context. This function was also } \\
\text { built based on visitors' } \\
\text { patterns explored in the pre- } \\
\text { study, namely that visitors tend } \\
\text { to walk in groups and have } \\
\text { conversations next to the } \\
\text { exhibited antiques. }\end{array}$ \\
\hline
\end{tabular}




\begin{tabular}{|c|c|c|c|}
\hline $\begin{array}{l}\text { Functions/ } \\
\text { Tasks }\end{array}$ & Description & Category & Purpose \\
\hline $\begin{array}{l}\text { Animated } \\
\text { characters }\end{array}$ & $\begin{array}{l}\text { As part of the scene design, } \\
\text { each character performs a } \\
\text { particular animation to } \\
\text { compose an epic and a } \\
\text { harmonic glimpse of ancient } \\
\text { Egyptian lifestyle. }\end{array}$ & $\begin{array}{l}\text { Visual } \\
\text { Communication }\end{array}$ & $\begin{array}{l}\text { This results in more influence } \\
\text { on the sense of immersion in } \\
\text { the mixed realms environment. }\end{array}$ \\
\hline $\begin{array}{l}\text { Tap to Place } \\
\text { portals }\end{array}$ & $\begin{array}{l}\text { A hand gesture to interact with } \\
\text { the scene portal and place them } \\
\text { next to the relevant antiques. It } \\
\text { is a protected function for } \\
\text { museum curators who can } \\
\text { access it through a combination } \\
\text { of a keyword and hand gesture. } \\
\text { Also, 'tap to place' is utilised } \\
\text { when the scene opens in front } \\
\text { of the physical item. It gives } \\
\text { the user the possibility to place } \\
\text { the scene wherever he/she } \\
\text { wants. }\end{array}$ & Interaction & $\begin{array}{l}\text { Working remotely with the } \\
\text { museum guidance system was } \\
\text { not easy to allocate the scene } \\
\text { portals by the system creator. } \\
\text { So, once the system creator } \\
\text { places these portals in their } \\
\text { right places, they will be } \\
\text { allocated at these pointed } \\
\text { forever. This function is also } \\
\text { protected from the user but not } \\
\text { protected for the museum } \\
\text { curators if they want to change } \\
\text { the exhibited items' locations. } \\
\text { Once the user accesses these } \\
\text { scene portals, they would see } \\
\text { an entire scene with a set of } \\
\text { visuals that can facilitate the } \\
\text { needed guidance for the } \\
\text { exhibited item. }\end{array}$ \\
\hline $\begin{array}{l}\text { Interactive } \\
\text { virtual replica } \\
\text { of an original } \\
\text { item }\end{array}$ & $\begin{array}{l}\text { Large-scale replicas of the } \\
\text { authentic exhibited items were } \\
\text { created to display virtually next } \\
\text { to the physical one. It is also } \\
\text { interactive to explore the } \\
\text { virtual replica from different } \\
\text { angles and observe details that } \\
\text { are not possible to perform in } \\
\text { the real museum. }\end{array}$ & $\begin{array}{l}\text { Guidance / } \\
\text { Interaction }\end{array}$ & $\begin{array}{l}\text { To add partially the sense of } \\
\text { controlling the object by } 3 \mathrm{D} \\
\text { interaction as the user controls } \\
\text { the authentic item. Hence, } \\
\text { visitors can rotate and move } \\
\text { the virtual replica as a sort of } \\
\text { compensation for touching } \\
\text { constraints that the visitor face } \\
\text { towards the authentic one. }\end{array}$ \\
\hline $\begin{array}{l}\text { User Interface } \\
\text { (Navigation } \\
\text { and Controls) }\end{array}$ & $\begin{array}{l}\text { It is a wide and curved user } \\
\text { interface that faces the user in } \\
\text { the antique's scene, where the } \\
\text { authentic item is placed next to } \\
\text { the visitor. }\end{array}$ & Interaction & $\begin{array}{l}\text { The user interface provides the } \\
\text { user with various types of } \\
\text { controls that lead to the growth } \\
\text { of the visitor's interactions } \\
\text { skills. It also provides the user } \\
\text { with the freedom to enter or } \\
\text { leave the scene whenever } \\
\text { he/she wants. }\end{array}$ \\
\hline
\end{tabular}

Table 1.0 List of MuseumEye functions 


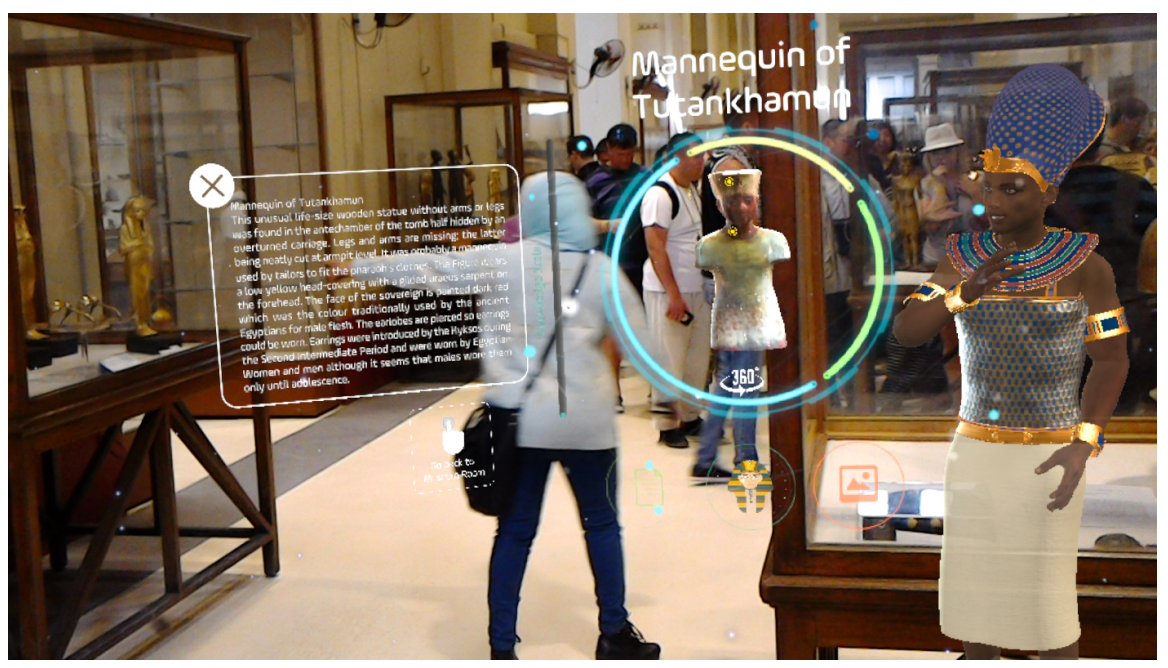

Fig. 1. Participants are observed while using the MR museum guide - MuseumEye

\subsection{System architecture}

The MR system developments always be constructed by creating 2D and 3D assets and gesture interactions that can fulfil the designed functions.

The creation and development of the MuseumEye system took four stages as depicted in Fig. 2:

1-User Interface: Designing the system's user interface requires the creation of UI design elements and UI interaction design.

2- Spatial Content Design: This process involves creating the interactive portal points which were designed to be placed in front of the exhibited items to open interactive scene to the particular antique. Also, it includes the creation of the location design of holographic objects.

3- Antique UI Panel: This stage involves creating all visual communicative functions such as images, videos, and 3D holographic of the antiques' replica.

4-3D Content Design: This stage includes creating 3D characters and 3D environment assets and all required assets for the narrative scenes.

We used Unity with HoloToolKit for developing the MR system with the 3D software packages such as Maya, zBrush and Substance Painter. Also, Microsoft Visual Studio has been adopted for deploying the application on the headset. 

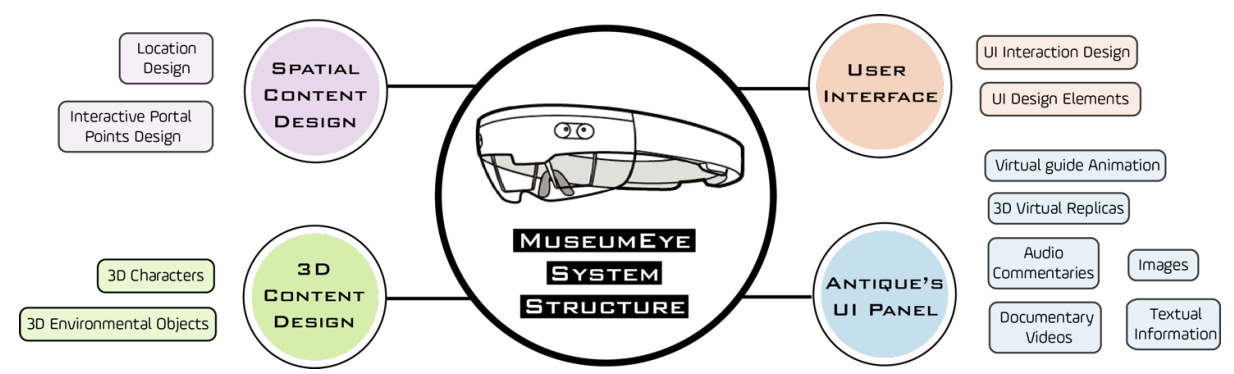

Fig. 2. MuseumEye content creation

\section{Method}

The observation method has been frequently in museums to understand visitors' behaviours (Bollo \& Dal Pozzolo, 2005; Lanir et al., 2017; Thrun et al., 1999). The observation method aims to record visitors' behaviours in the actual environment regarding the antiques exhibited. These behaviours include their movements, time spent next to/ in front of the antique, and how they react. The other aim of using observation is to conduct a critical comparison between the human behaviours in the current state of museum guidance and these same behaviours after applying the research solution. This comparison can visually demonstrate the differences in the engagement level and highlight the significance of using MR gadgets in museum tours.

171 of the daily museum visitors participated and observed in this experiment. This sample size was equal to the study conducted by Rubino, Xhembulla, Martina, Bottino, and Malnati (2013). Many museum studies relied on specific measurements to assess how people were attracted to exhibits such as 'Holding Power' (Bollo \& Dal Pozzolo, 2005; Hooper-Greenhill, 2006; Lanir et al., 2017; Serrell, 1997).

'Holding Power' is measured by calculating the total time spent in front of an exhibit, and is used to measure the visitor's interest. This measurement informs the preliminary

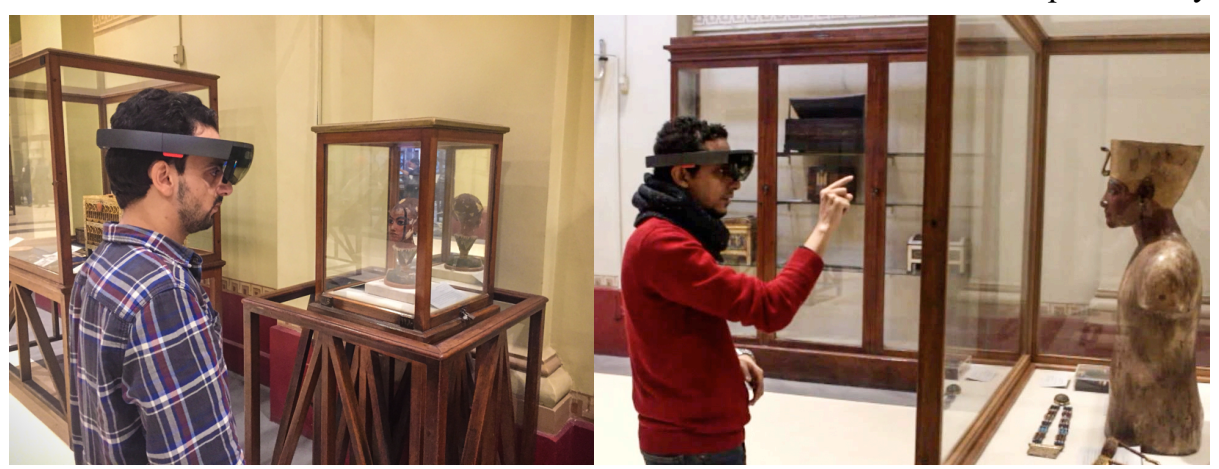

idea of the power of an exhibit to hold the interest of a visitor (Bitgood, 2017).

Fig. 3. Participants are observed while using the MR museum guide - MuseumEye 


\section{Results}

After observing the 171 participants during experimenting MuseumEye next to the targeted antiques, it was found that:

Time spent on exhibited items: the average time a visitor spent in front of each exhibited item was 177 seconds ( $=3$ minutes).

In order to get the "Holding Power Index", the utilisation time necessary is needed to be defined. According to several interviews with experts and curators who work in this museum room, the antiques adopted for observation require from 1 to 2 minutes (90 seconds) as sufficient time to stay next to each of them for gazing and reading labels. This value represents the 'utilisation time necessary', which is required for the later observation analysis.

Holding Power index $=\frac{\text { Avarage stopping time }}{\text { Utilisation time necessary }}=177 \div 90=1.96$

This measurement informs the preliminary idea of the power of an exhibit to hold the interest of a visitor (Bitgood, 2017).

As mentioned earlier, the preliminary observation studies measured the average of the time spent is 40 seconds.

Holding Power index $=\frac{\text { Avarage stopping time }}{\text { Utilisation time necessary }}=40 \div 90=0.4$

The observation included the consuming of the content as the participant kept watching the virtual guide from 10 to 100 seconds, with an average of 36 seconds. Also, the spent from 1-8 minutes on the storytelling scenes with an average of 6 minutes.

The observation captured six different patterns on behaviours. The first pattern was that some participants seemed to be hesitant in using the MR system, especially with performing the hand interactions. Therefore, they asked for assistance during their tour. Regarding the second pattern, the observational camera and the written notes captured that some of the participants were smiling before, during or after their tour. The third pattern was that there were some participants who seemed familiar and confident with the system during the tour, as they did not ask for assistance and kept walking freely. The fourth pattern revealed a group of participants who had the same attitude of exploring the environment and keeping moving around themselves to discover the surrounding virtual world. The fifth pattern exposed a group of participants who accidentally faced crowds in front of their faces. This might obstruct the spatial visuals or cause issues with interactions' functionality, however, they seemed stable and engaged with the storytelling demonstrations. Furthermore, the sixth pattern represented a group of participants who were witnessed talking and smiling to their peers as they were trying to inform them what they could see.

\section{Discussion and Conclusion}

Time has been adopted as a robust and unobtrusive measure of museum visitors' attention (J. H. Falk, 1982; Serrell, 1995). The aim of designing MuseumEye and employing it in the Egyptian Museum in Cairo was achieved which extends the time 
that visitors spent in the museum. When comparing the results between the observation of the exploratory study and during the usage of the guide system, the Holding power increased from 0.4 to 1.96 respectively (from 40 seconds as an average to 177 seconds). According to Bollo and Dal Pozzolo (2005) "The closer it is to 1, the greater the ability of the element to hold the visitors' attention will be". Therefore, the system was able to draw visitors' attention to the visuals seen around the exhibited antiques and the interaction they had to perform to gain more knowledge. Also, MuseumEye as a guide system can draw the attention of the three types of museum visitors: the greedy visitor, the selective visitor, and the busy visitor, which were categorised by Sparacino (2002).

Comparing the outcomes of the observation's statistics of this study with other studies that adopt technologies to extend visiting time, it was concluded that MuseumEye could extend the time much higher than other studies did. This study increased visiting time by $440 \%$ compared to the time visitors used to stay in the same room. When reviewing other studies, it was found that a study was conducted by Proctor and Tellis (2003), who were able to extend the time spent from 45-minutes using portable audio to 55minutes using a multimedia tour pilot. Another study also extended the time from 49.6 minutes without using guides to 59.3 minutes with using a museum guide (Lanir, Kuflik, Dim, Wecker, \& Stock, 2013). Moreover, an old study (Robinson, 1928) aimed to extend the time spent using a pamphlet guide, which increased from 17 minutes (unguided) to 28 minutes (guided). Another project could extend the spent time from 5 minutes to 10 minutes using a mobile guide (Wang et al., 2009). A mobile application used to boost the engaging time in museums for students from - as an average - 92 seconds to 117 seconds compared with the usage of worksheets (Cahill et al., 2011). AR tools also has been used to expand the time of interacting and learning in museums from 133.28 to 206.74 seconds (Yoon \& Wang, 2014). Another study calculated the time consumed by visitors who used the guidebook as it resulted 20,57 seconds compared to who did not use it which resulted 13.26 seconds.

If MuseumEye was adopted by the museum and scaled to include numerous collections of the museum antiques, visitors could spend many hours, which could result in days' worth of exploration, instead of approximately one hour in the regular visits.

\subsection{Future work}

Based on the adopted approach, many activities can be held in museum rooms to boost the attraction levels in museums (Smith, Gomez, \& Cortes-Rivera, 2019). Interactive holographic games can be designed to be played within the museum, based on quests that can be requested from visitors e.g. collect relevant relics or shooting historical villains.

\section{Acknowledgements}

We are very thankful to the experts and professionals from the Egyptian Museum in Cairo who contributed to this research. Also, we would like to thank NewtonMosharafa scholarship for funding this research. 


\section{References}

Bitgood, S. (2017). Museum Fatigue: A Critical Review. Visitor studies, 12(2), 93-111. doi:10.1080/10645570903203406

Bollo, A., \& Dal Pozzolo, L. (2005). Analysis of visitor behaviour inside the museum: an empirical study. Paper presented at the Proceedings of the 8th international conference on arts and cultural management.

Brida, J. G., Nogare, C. D., \& Scuderi, R. (2017). Learning at the museum: Factors influencing visit length. Tourism Economics, 23(2), 281-294.

Brodie, R. J., Ilic, A., Juric, B., \& Hollebeek, L. (2013). Consumer engagement in a virtual brand community: An exploratory analysis. Journal of business research, 66(1), 105-114.

Cahill, C., Kuhn, A., Schmoll, S., Lo, W.-T., McNally, B., \& Quintana, C. (2011). Mobile learning in museums: how mobile supports for learning influence student behavior. Paper presented at the Proceedings of the 10th International Conference on Interaction Design and Children.

Chia, W. C., Yeong, L. S., Lee, F. J. X., \& Ch'ng, S. I. (2016). Trip planning route optimization with operating hour and duration of stay constraints. Paper presented at the Computer Science \& Education (ICCSE), 2016 11th International Conference on.

Darzentas, D., Flintham, M., \& Benford, S. (2018). Object-focused mixed reality storytelling: technology-driven content creation and dissemination for engaging user experiences. Paper presented at the Proceedings of the 22nd Pan-Hellenic Conference on Informatics.

Dwayne Ball, A., \& Tasaki, L. H. (1992). The role and measurement of attachment in consumer behavior. Journal of Consumer Psychology, 1(2), 155-172.

Edmonds, E., Muller, L., \& Connell, M. (2006). On creative engagement. Visual communication, 5(3), 307-322.

Falk, J., \& Storksdieck, M. (2005). Using the contextual model of learning to understand visitor learning from a science center exhibition. Science education, 89(5), 744-778.

Falk, J. H. (1982). The use of time as a measure of visitor behavior and exhibit effectiveness. Roundtable Reports, 7(4), 10-13.

Higgins, E. T., \& Scholer, A. A. (2009). Engaging the consumer: The science and art of the value creation process. Journal of Consumer Psychology, 19(2), 100-114.

Holloway-Attaway, L., \& Rouse, R. (2018). Designing postdigital curators: establishing an interdisciplinary games and mixed reality cultural heritage network. In Advances in Digital Cultural Heritage (pp. 162-173): Springer.

Hooper-Greenhill, E. (2006). Studying visitors. A companion to museum studies, 362376.

Hou, W. (2019). Augmented Reality Museum Visiting Application based on the Microsoft HoloLens. Paper presented at the Journal of Physics: Conference Series.

Lanir, J., Kuflik, T., Dim, E., Wecker, A. J., \& Stock, O. (2013). The influence of a location-aware mobile guide on museum visitors' behavior. Interacting with Computers, 25(6), 443-460. 
Lanir, J., Kuflik, T., Sheidin, J., Yavin, N., Leiderman, K., \& Segal, M. (2017). Visualizing museum visitors' behavior: Where do they go and what do they do there? Personal and Ubiquitous Computing, 21(2), 313-326.

Marci, C. D. (2006). A biologically based measure of emotional engagement: Context matters. Journal of Advertising Research, 46(4), 381-387.

Microsoft. (2015). Microsoft HoloLens. Retrieved from https://www.microsoft.com/en-us/hololens/buy

Pollalis, C., Fahnbulleh, W., Tynes, J., \& Shaer, O. (2017). HoloMuse: Enhancing engagement with archaeological artifacts through gesture-based interaction with holograms. Paper presented at the Proceedings of the Tenth International Conference on Tangible, Embedded, and Embodied Interaction.

Pollalis, C., Gilvin, A., Westendorf, L., Futami, L., Virgilio, B., Hsiao, D., \& Shaer, O. (2018). ARtLens: Enhancing Museum Visitors' Engagement with African Art. Paper presented at the Proceedings of the 2018 ACM Conference Companion Publication on Designing Interactive Systems.

Proctor, N., \& Tellis, C. (2003). The State of the Art in Museum Handhelds in 2003.

Robinson, E. S. (1928). The Behavior of the Museum Visitor.

Rubino, I., Xhembulla, J., Martina, A., Bottino, A., \& Malnati, G. (2013). Musa: Using indoor positioning and navigation to enhance cultural experiences in a museum. Sensors, 13(12), 17445-17471.

Serrell, B. (1995). The 51\% solution research project: A meta-analysis of visitor time/use in museum exhibitions. Visitor Behavior, 10(3), 6-9.

Serrell, B. (1997). Paying attention: The duration and allocation of visitors' time in museum exhibitions. Curator: The Museum Journal, 40(2), 108-125.

Smith, J., Gomez, K., \& Cortes-Rivera, A. (2019). Yes, you can still touch this: Playtesting interactive prototypes for museum spaces. Paper presented at the iConference Proceedings.

Sparacino, F. (2002). The Museum Wearable: Real-Time Sensor-Driven Understanding of Visitors' Interests for Personalized Visually-Augmented Museum Experiences.

Taheri, B., Jafari, A., \& O'Gorman, K. (2014). Keeping your audience: Presenting a visitor engagement scale. Tourism Management, 42, 321-329.

Thrun, S., Bennewitz, M., Burgard, W., Cremers, A. B., Dellaert, F., Fox, D., . . . Schulte, J. (1999). MINERVA: A second-generation museum tour-guide robot. Paper presented at the Robotics and automation, 1999. Proceedings. 1999 IEEE international conference on.

Wang, Y., Stash, N., Sambeek, R., Schuurmans, Y., Aroyo, L., Schreiber, G., \& Gorgels, P. (2009). Cultivating personalized museum tours online and on-site. Interdisciplinary science reviews, 34(2-3), 139-153.

Welsh, P. H. (2005). Re-configuring museums. Museum Management and Curatorship, 20(2), 103-130.

Yoon, S. A., \& Wang, J. (2014). Making the invisible visible in science museums through augmented reality devices. TechTrends, 58(1), 49-55.

Yoshimura, Y., Krebs, A., \& Ratti, C. (2016). An analysis of visitors' length of stay through noninvasive Bluetooth monitoring in the Louvre Museum. arXiv preprint arXiv:1605.00108. 